Reprod. Nutr. Dévelop., 1987, 27 (3), 715-719.

\title{
Early stages of embryonic development in two rabbit genotypes
}

\author{
Suzanne TORRĖS, Françoise HULOT $\left({ }^{*}\right)$, Claude SEVELLEC \\ Station de Physiologie animale, I.N.R.A., \\ 78350 Jouy-en-Josas, France. \\ (*) Station d'Amélioration génétique des Animaux, I.N.R.A., \\ B.P. 27, 31326 Castanet-Tolosan.
}

Summary. The origin of the early embryonic loss that occurs during the first 4 days after mating in Californian doe-rabbits has been studied at $24 \mathrm{~h}$ or $60 \mathrm{~h}$ post coitum (p.c.). For comparison, 11 New Zealand doe-rabbits were slaughtered at the same times. The development stage of the embryo was determined after examination in toto at $24 \mathrm{~h}$ or by counting the morula nuclei at $60 \mathrm{~h}$ on histological sections.

At 24 h p.c., $5.3 \%$ of the New Zealand eggs had not divided vs $37 \%$ of the Californian ones ; this difference was highly significant. At 60 h p.c. frequency histograms of the number of morula iuclei showed that development was more variable in Californian does than in the New Zealand ones. However, the mean number of morula nuclei of each genotype was not significantly different.

The higher proportion of Californian eggs (compared to New Zealand eggs) that were unfertilized or showed retarded segmentation is the main cause of the unexpectely lower prolificacy of Californian rabbits.

\section{Introduction.}

In a preceding paper we have shown that a high proportion of abnormal eggs and embryos at day 4 was the main cause of the lower prolificacy of Californian rabbits.

To determine the relative importance of the success of fertilization and of abnormal or delayed cleavage in this early embryonic loss, we recovered eggs $24 \mathrm{~h}$ and $60 \mathrm{~h}$ post coitum (p.c.) when they were still in the fallopian tube.

\section{Material and methods.}

In a first series of experiments, 7 Californian doe-rabbits and 11 New Zealand doe-rabbits were killed $24 \mathrm{~h}$ after mating with a male of the same genotype. The number of corpora lutea was counted and the eggs recovered from oviduct 
flushings with PBS + fetal calf serum (FCS). The blastomeres of the recovered eggs were counted under a binocular microscope $(x 160)$.

In a second series of experiments, 6 doe-rabbits of each genotype were killed at $60 \mathrm{~h}$ p.c. The oviduct and about the proximal one-third of the uterine horn were perfused and the corpora lutea in each uterine horn were counted. Recovered eggs were fixed in Bouin Hollande and then embedded in gelose and paraffin. The number of morula nuclei was counted on $15 \mu \mathrm{m}$ serial sections and the mitotic activity estimated by the number of mitoses.

\section{Results.}

Experiment 1. - The 7 Californian does had a mean of $11.6 \pm 3.1$ ovulations (81 corpora lutea). Ovulation rate was $8.7 \pm 2$ ovulations (96 corpora lutea) in 11 New Zealands. This difference in ovulation rate between the two genotypes has already been reported (see Hulot and Matheron, 1981).

The mean number of eggs recovered were $9.7 \pm 4.5$ (Californian) and $6.9 \pm 3.5$ (New Zealand), respectively, indicating a loss of $16 \%$ and $21 \%$; these percentages were particularly high for normal ovulatory females. In three New Zealand does, flushings of one side of the oviduct gave no eggs, in spite of good manipulations.

Normally, the first division in fertilized eggs occurred between 22 and $24 \mathrm{~h}$ p.c. ; the second division occurred $6 \mathrm{~h}$ after the first one. At $24 \mathrm{~h}$ we found unsegmented eggs, eggs with 2 blastomeres (which were either equal or unequal) and eggs with 4 blastomeres.

We recovered $89.5 \%(68 / 76)$ cleaved eggs with 2 equal or unequal blastomeres in New Zealand does and $57.3 \%$ (39/68) in Californian ones. $37 \%$ (25/68) of Californian eggs were not cleaved (Fig. 1a) and $5.3 \%(4 / 76)$ of New Zealand ones. The difference was highly significant $(P<0.005)$. Of the segmented Californian eggs : $44 \%(30 / 68)$ had equal blastomeres and $13 \%$ unequal ones ; in the New Zealand $77.6 \%(59 / 76)$ and $15.8 \%(12 / 76)$, respectively, were found (Figs $1 b, c)$. The difference was highly significant $(P<0.005)$ for equal blastomeres but not for unequal ones. Four embryos with 4 blastomeres each were found in the Californian does, and one fragmented one with about 12 cells in New Zealands (Fig. 1d).

Experiment 2. - At $60 \mathrm{~h}$ p.c., 6 Californian does had a mean of $11.2 \pm 1$ corpora lutea (67). Six New Zealands had 8.8 ovulations (53). This difference was already found. Sixty-six eggs and morulae $(98.5 \%)$ were recovered in Californians and $96 \%$ in New Zealands.

In Californian does 11 eggs were not fertilized (16.6\%), 50 were normal morulae $(75 \%)$ and 5 degenerated morula $(7.6 \%)$. In New Zealands all the 51 embryos recovered were normal morulae $(100 \%)$.

Two frequency histograms of the number of morula nuclei were plotted for each genotype (Fig. 2). There was no significant difference between the mean number of morula nuclei of the two genotypes; however frequency distribution curves were clearly different. 


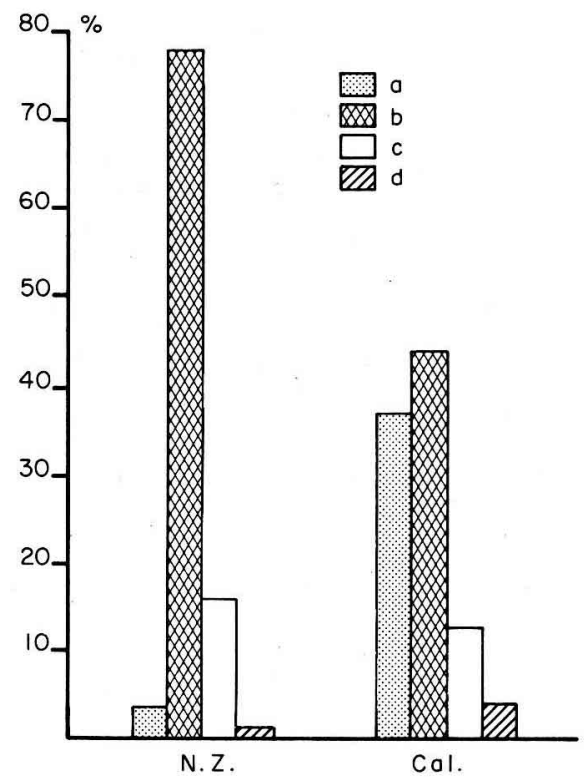

FIG. 1. - Different eggs distribution. - $a, b, c, d:$ Percentage in relation to the No. of recovered eggs : a, unsegmented eggs ; $b$, segmented eggs ; 2 equal blastomeres ; c) segmented eggs, 2 inequal blastomeres; $d$, segmented eggs, 4 blastomeres and 12 blastomeres.

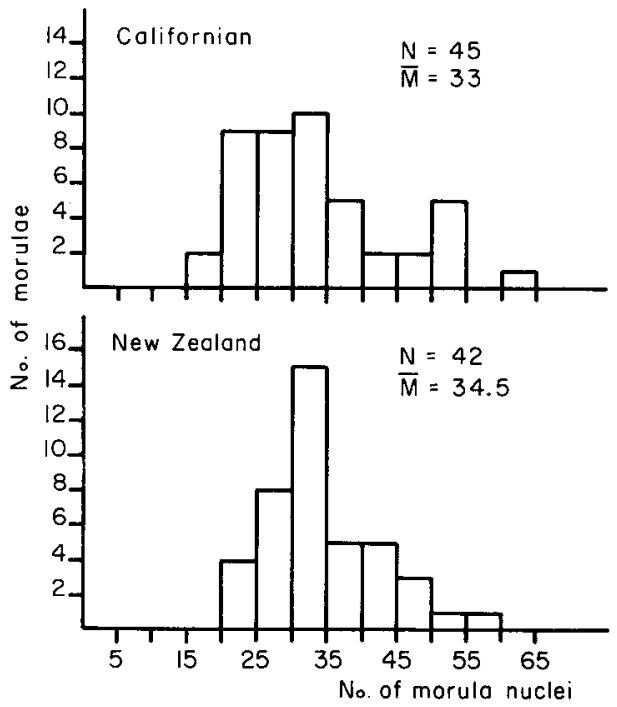

FIG. 2. - Frequency histogram showing morula cells distribution. 
Californian morula cells had a wider distribution than New Zealand ones, mainly due to the higher percentage of delayed embryos ; $44 \%$ had $15-30$ nuclei vs 28 of the New Zealand morulae.

One doe in each strain had one accelerated cleavage with a higher mitotic index.

Mitotic activity gives a good indication of morula viability. The mean number of mitoses in the New Zealands varied between 0.7 and 1.8 and between 0 and 1.9 in Californians. One rabbit with 0 mitoses (in 6 morulae) had more than 5 eggs with retarded segmentation and degenerated nuclei. The 6 morulae would probably have degenerated later. These 11 embryos contributed to the spreadout appearance of the frequency histogram of the Californians and were included in the $44 \%$ of degenerated embryos.

\section{Discussion.}

To explain the difference in prolificacy between the two strains, Californian and New Zealand, due to embryonic loss before $96 \mathrm{~h}$ (Torrès et al., 1987) mated rabbits were killed at $24 \mathrm{~h}, 60 \mathrm{~h}$ and $96 \mathrm{~h}$ p.c. These different stages permitted us to compare the respective proportions of embryos which developed normally in the two strains and to determine the critical periods of degeneration.

There was a higher proportion of uncleaved eggs in Californian does than in New Zealand ones, at 24 h p.c. ( $37 \%$ vs $5.3 \%$ ). Delayed and degenerated eggs were also more frequent in Californians than in New Zealands at $24 \mathrm{~h}$ p.c. $(5.9 \mathrm{vs}$ 1.3). At 60 h p.c. $7.6 \%$ Californian embryos had a delayed cleavage vs $0 \%$ in New Zealand.

At $96 \mathrm{~h}$ the mean number of normal blastocysts was 8.9 in Californians and 8.2 in New Zealands. These means are about equal to the number of young born (Torrès et al., 1987).

The flattening of the distribution patterns of the number of morula cells in Californians confirms that delayed fertilization occurred. This hypothesis fits well with the relative high percentage of uncleaved eggs in this strain. As embryos at the 4-cell stage were only observed in Californian does $24 \mathrm{~h}$ p.c., the high proportion of uncleaved eggs at this time in this strain cannot be explained by a longer first cell cycle but rather by a delayed fertilization or a wider ovulation period.

The delayed embryo cleavage could be due also to sperm defect and sperm transport and consequently needs further research on male fertility of the Californian strains.

In mice Mc Laren and Bowman (1973) have shown that the timing difference in early development in five strains was due to the time at which cleavage began and not to the rate of cleavage. The regression lines calculated for two genotypes were parallel. Genetic effects in early mouse development are also demonstrated by Golbard et al. (1982a, b).

For Molls et al. (1983) the comparative duration of cell cycle phases is due to genetic effect and the proliferation rates are considered to be strain specific. 


\section{Conclusion.}

The lower prolificacy of Californian strain is due to the higher proportion of unfertilized eggs and degeneration after fertilization, specially at the morula stage. Fertilization is probably perturbed either because ovulation is spread out or because the sperms and then transport are defective.

Reçu en décembre 1986. Accepté en mars 1987.

Acknowreagements. - We wish to thank Miss Solari for statistical analysis and Mrs Daifuku for the English translation.

Résumé. Etude des stades précoces de développement embryonnaire dans deux génotypes de lapine.

L'origine de la mortalité embryonnaire précoce qui survient pendant les 4 premiers jours après l'accouplement chez les lapines californiennes a été recherchée en sacrifiant 13 lapines 24 h p.c. Ou 60 h p.c. Par comparaison, 11 lapines néo-zélandaises ont été abattues à $24 \mathrm{~h}$ p.c. et $60 \mathrm{~h}$ p.c. Le stade de développement a été déterminé après examen in toto à $24 \mathrm{~h}$ p.c. ou par dénombrement des noyaux des morulae de $60 \mathrm{~h}$ p.c. sur coupes histologiques.

A 24 h p.c., 5,3 \% des cufs des néo-zélandaises ne sont pas divisés contre $37 \%$ chez les californiennes; la différence est hautement significative. Deux histogrammes de fréquence du nombre de noyaux des morulae montrent que les californiennes présentent une plus grande variabilité de développement que les néo-zélandaises. A 60 h p.c., le nombre moyen de noyaux des morulae de chaque souche n'est pas significativement différent ; cependant, on observe des retards de segmentation avec dégénérescence des noyaux chez des embryons de californiennes.

La proportion plus élevée d'œufs non fécondés et en retard chez les californiennes fait supposer un retard de fécondation.

L'étalement des ovulations ou la qualité des spermatozoïdes et les conditions de leur transit dans le tractus génital femelle peuvent être responsables des échecs observés dans la fécondation et le développement des embryons.

\section{References}

GOLBARD S. B., VERBANAC K. M., WARNER C., 1982a. Role of the $\mathrm{H}-2$ complex in preimplantation mouse embryo development. Biol. Reprod., 26, 591-596.

GOLBARD S. B., WARNER C., 1982b. Genes affect the timing of early mouse embryo development. Biol. Reprod., 27, 419-424.

HULOT F., MATHERON G., 1981. Effets du génotype, de l'âge et de la saison sur les composantes de la reproduction chez la lapine. Ann. Génét. Sél. anim., 13, 131-150.

MC LAREN A., BOWMAN P., 1973. Genetic effects on the timing of early development in the mouse. J. Embryol. exp. Morph., 30. 491-498.

MOLLS M., ZAMBOGLOU N., STREFFER C., 1983. A comparison of the kinetics of pre-implantation mouse embryos from two different mouse strains. Cell Tissue Kinet., 16, 277-283.

TORRĖS S., HULOT F., MEUNIER M., SEVELLEC C., 1987. Comparative study of embryonic development and loss in two rabbit genotypes. Reprod. Nutr. Dévelop., 27, 707-714. 